\title{
Antibacterial activity of clove (Syzygium aromaticum) and cinnamon (Cinnamomum burmannii) essential oil against extended-spectrum $\beta$-lactamase-producing bacteria
}

\author{
Elgio Venanda Ginting ${ }^{1}$, Endah Retnaningrum² ${ }^{2}$ and Dyah Ayu Widiasih ${ }^{1}$ (D)
}

\author{
1. Faculty of Veterinary Medicine, Universitas Gadjah Mada, Yogyakarta, Indonesia; 2. Faculty of Biology, Universitas \\ Gadjah Mada, Yogyakarta, Indonesia. \\ Corresponding author: Dyah Ayu Widiasih, e-mail: dyahaw@ugm.ac.id \\ Co-authors: EVG: elgio.venanda@mail.ugm.ac.id, ER: endahr@ugm.ac.id \\ Received: 23-03-2021, Accepted: 13-07-2021, Published online: 25-08-2021
}

doi: www.doi.org/10.14202/vetworld.2021.2206-2211 How to cite this article: Ginting EV, Retnaningrum E, Widiasih DA (2021) Antibacterial activity of clove (Syzygium aromaticum) and cinnamon (Cinnamomum burmannii) essential oil against extended-spectrum $\beta$-lactamase-producing bacteria, Veterinary World, 14(8): 2206-2211.

\begin{abstract}
Background and Aim: Extended-spectrum $\beta$-lactamase (ESBL) is an enzyme produced by the family of Enterobacteriaceae, especially Escherichia coli and Klebsiella pneumoniae, which can hydrolyze $\beta$-lactam antibiotics, such as penicillins, cephalosporins, cephamycin, and carbapenem. ESBL-producing bacteria are widely distributed from farms to slaughterhouses until food products originating from animals are available in the market, which plays an important role as a pathway for the exposure and transmission of ESBL-producing bacteria from food products of animal origin to humans. This study aimed to determine the antibacterial activity of Syzygium aromaticum (clove) and Cinnamomum verum (cinnamon) essential oils against strains resistant to ESBL-producing E. coli and $K$. pneumoniae isolates.
\end{abstract}

Materials and Methods: The antibacterial activity of clove and cinnamon essential oils was tested against three strains of tested bacteria using the disk diffusion method. The minimum inhibitory concentration (MIC) of clove and cinnamon essential oils was determined using the broth microdilution method. The minimumbactericidal concentration (MBC) was determined using the MIC. Morphological changes on each tested bacteria were observed through scanning electron microscopy (SEM).

Results: Both essential oils exhibited inhibitory effects toward all test organisms, indicated by inhibition zones around the disk. The MIC values of clove essential oil were $0.078 \%(\mathrm{v} / \mathrm{v})$ for all tested bacteria, whereas the MICs of cinnamon essential oil ranged from $0.039 \%(\mathrm{v} / \mathrm{v})$ to $0.156 \%(\mathrm{v} / \mathrm{v})$ for all tested bacteria. MBC values of clove and cinnamon essential oils ranged from $0.078 \%(\mathrm{v} / \mathrm{v})$ to $0.156 \%(\mathrm{v} / \mathrm{v})$ for all tested bacteria. There were morphological changes in each tested bacterial cell that was observed through SEM. Each tested bacteria treated with clove and cinnamon essential oils showed shrinkage and cells lysis.

Conclusion: It was concluded that clove and cinnamon essential oils have emerged as effective antibacterial agents by showing high antibacterial activity against ESBL-producing E. coli and $K$. pneumoniae isolates, as evidenced by the inhibition zone diameter and MIC value.

Keywords: cinnamon (Cinnamomum burmannii), clove (Syzygium aromaticum), extended-spectrum $\beta$-lactamase, essential oils, Escherichia coli, Klebsiella pneumoniae.

\section{Introduction}

Extended-spectrum $\quad \beta$-lactamase (ESBL)producing bacteria developed as a zoonotic issue, resistant to various antibiotics. It is currently the main challenge in treating diseases, which bacterial agents cause. Antibacterial resistance and food safety issues have become a global concern recently due to their major impact on public health and the global economy.

Resistant bacteria that contaminate food raise concerns about food safety. Therefore, research to find new antibacterial agents from natural sources

Copyright: Ginting, et al. Open Access. This article is distributed under the terms of the Creative Commons Attribution 4.0 International License (http://creativecommons.org/licenses/ by/4.0/), which permits unrestricted use, distribution, and reproduction in any medium, provided you give appropriate credit to the original author(s) and the source, provide a link to the Creative Commons license, and indicate if changes were made. The Creative Commons Public Domain Dedication waiver (http:// creativecommons.org/publicdomain/zero/1.0/) applies to the data made available in this article, unless otherwise stated. is necessary [1]. Natural antibacterials derived from plant and bacterial metabolites as food additives are currently being promoted to replace synthetic antibacterials [2-4]. This can be used to protect the safety of consumers and food products. In the food industry, antibacterials are used for two essential reasons: Ensuring the preservation of food products and inhibiting the growth of microorganisms in food products [5].

The largest antibacterial components contained in Syzygium aromaticum (clove) and Cinnamomum verum (cinnamon) essential oils are eugenol in clove and cinnamaldehyde in cinnamon, which have had antibacterial activity against foodborne pathogens [6-8]. Klebsiella pneumoniae cells treated with eugenol have shown cell membrane destruction and cell swelling [9]. Cinnamaldehyde has been reported to inhibit Escherichia coli, increase cell membrane permeability, and oxidize the cell 
membrane [10]. Eugenol in clove and cinnamaldehyde in cinnamon can cause lysis to bacterial membranes and inhibit $\beta$-lactamase production in $E$. coli, as previously reported [11]. Previous studies also reported that clove and cinnamon essential oils can enhance the shelf life of chicken meat $[12,13]$. In this research, we test the antibacterial activity of clove and cinnamon essential oils against ESBLproducing bacteria.

This study aimed to determine the antibacterial activity of clove and cinnamon essential oils against strains resistant to ESBL-producing $E$. coli and K. pneumoniae isolates.

\section{Materials and Methods}

\section{Ethical approval}

This study did not involve living creatures, either both animals and humans as research subjects, so it does not require ethical approval.

\section{Study period and location}

This study was conducted from July to December 2020. The antibacterial activity of clove and cinnamon essential oils were tested at the Veterinary Public Health Laboratory, Faculty of Veterinary Medicine, and Microbiology Laboratory Faculty of Biology,

\section{Test organisms}

Two isolates standard of E. coli (ATCC 25922) and $K$. pneumoniae (ATCC 700603) obtained from the culture collection at Microbiology Laboratory, Faculty of Medicine, Gadjah Mada University, were used in this study. In addition, E. coli-producing ESBL isolates originating from chicken meat in traditional markets (CM ESBL-EC) was obtained from the culture collection at the Veterinary Public Health Laboratory, Faculty of Veterinary Medicine, Gadjah Mada University. All cultures were stored in the slant agar at $4^{\circ} \mathrm{C}$, and it was used as a stock culture for 14 days.

\section{Identification and authentication of the plants used in this research}

The clove and cinnamon used in this research have been identified at the Laboratory of Plant Systematic, Faculty of Biology, Universitas Gadjah Mada, Yogyakarta, Indonesia, by the botanist Ludmilla Fitri Untari, S.Si., M.Sc.

\section{Isolation and preparation of clove and cinnamon essential oils \\ Clove bud was obtained from farmers} in Girimulyo Village, Kulon Progo Regency, Yogyakarta, whereas the cinnamon bark was obtained from Kledung Village, Temanggung Regency, Central Java. Clove and cinnamon essential oils were distilled using the steam distillation method, according to Masango [14]. First, $1 \mathrm{~kg}$ of clove flowers and $2 \mathrm{~kg}$ of cinnamon bark were crushed. Steam distillation was done by placing the crushed clove flowers and cinnamon bark on the Universitas Gadjah Mada, Indonesia.

shelf, and then, water was boiled under the kettle shelf. The kettle was heated using an electric stove. The distillation time took $4 \mathrm{~h}$, and it was measured from the first condensate drop. The material and water were separated using a sieve (filter). A sieve was placed under the water surface to avoid direct contact between the water and material, leaving only the essential oils.

\section{Chemical composition of the essential oil obtained}

For the chemical composition of clove buds and cinnamon bark essential oils, we refer to previous research using the same plant from the exact origin $[15,16]$, as shown in Tables- 1 and 2.

\section{Antibacterial sensitivity testing}

The antibacterial activity of clove and cinnamon essential oils was tested on the basis of the method used by Balouiri et al. [17] and Gulfraz et al. [18] with modification. First, each bacterium was subcultured in nutrient broth (Merck, Darmstadt, Germany) for $24 \mathrm{~h}$ at $37^{\circ} \mathrm{C}$. Then, $150 \mu \mathrm{L}$ of standardized inoculum $\left(10^{8}\right.$ colony-forming unit $[\mathrm{CFU}] / \mathrm{mL}$; 0.5 McFarland) of each bacterium tested was spread onto sterile MuellerHinton agar (MHA) (Merck, Darmstadt, Germany) to achieve confluent growth.

Table-1: Chemical composition (relative percentage, extreme values) of clove bud (Syzygium aromaticum).

\begin{tabular}{lc}
\hline Compounds & Percentage \\
\hline Methyl salicylate & $0.04-0.16$ \\
Chavicol & $0.13-0.18$ \\
Eugenol & $77.32-82.36$ \\
$\alpha$-Copaene & $0.17-0.27$ \\
methyl eugenol & $0.04-0.08$ \\
$\beta$-Caryophyllene & $5.34-8.64$ \\
Isoeugenol & $0.02-0.24$ \\
a-Humulene & $0.65-1.04$ \\
Eugenyl acetate & $8.61-10.55$ \\
Caryophyllene oxide & $0.06-0.32$ \\
\hline
\end{tabular}

Table-2: Chemical composition of cinnamon bark (Syzygium aromaticum).

\begin{tabular}{lc}
\hline Compounds & Percentage \\
\hline Styrene & 0.62 \\
IR- $\alpha$-pinene & 1.68 \\
Camphene & 0.88 \\
Benzaldehyde & 1.21 \\
$\beta$-Pinene & 0.64 \\
Eucalyptol & 3.46 \\
Benzene propanol & 2.11 \\
Borneol & 0.70 \\
3-Cyclohexen-1ol & 1.04 \\
p-Ment-1-eu-8-ol & 1.04 \\
Cinnamaldehyde & 61.16 \\
Benzene propanol & 0.89 \\
Copaene & 3.54 \\
Caryophyllene & 0.75 \\
2H-1-Benzopyran-2-one & 1.16 \\
2-Propen-1-ol, 3-phenyl-acetat & 1.46 \\
$\alpha$-Caryophyllene & 0.55 \\
Naphthalene & 8.94 \\
$\alpha$-Cubebene & 0.00 \\
Caryophyllene oxide & 0.98 \\
\hline
\end{tabular}


The Whatman blank disks with a diameter of $6 \mathrm{~mm}$ were sterilized; then, $10 \mathrm{~L}$ essential oil was injected, which was diluted with dimethyl sulfoxide (DMSO) to achieve reduction concentration ranged between $40 \%, 20 \%$, and $10 \%(\mathrm{v} / \mathrm{v})$ and placed on the agar surface under aseptic conditions. Sterile DMSO served as the negative control, and chloramphenicol disks (Oxoid, Dublin, Ireland) were a positive control. The inoculated plate was incubated at $37^{\circ} \mathrm{C}$ during 18-24 $\mathrm{h}$. Then, antibacterial activity was evaluated by measuring the zone of inhibition $(\mathrm{mm})$ against the test organism. Each antibacterial activity test was repeated thrice.

\section{Determination of minimum inhibitory concentra- tion (MIC) and minimum bactericidal concentration (MBC) of cloves and cinnamon essential oils}

To obtain the minimum concentration of clove and cinnamon essential oils to inhibit all tested bacteria (MIC), a microdilution test was conducted. The test was conducted according to Adukwu et al. [19]. Each tested bacteria $\left(10^{8} \mathrm{CFU} / \mathrm{mL}\right.$; $0.5 \mathrm{McF}$ arland) was inoculated into nutrient broth (Merck) at $50^{\circ} \mathrm{C}$. Nutrient broth and cultures without essential oils added to wells of a sterile 96-well microplate were a positive control, whereas nutrient broth without cultures was the negative control.

Each essential oil was diluted with DMSO to obtain $2.5 \%$ essential oil concentrations. Then, $100 \mu \mathrm{L}$ of each dilution of essential oils was transferred into nutrient broth containing each tested bacteria (1:1) and added to wells to give final essential oil concentrations of $1.25 \%, 0.625 \%, 0.312 \%, 0.156 \%, 0.078 \%$, $0.039 \%$, and $0.019 \%(\mathrm{v} / \mathrm{v})$. Optical density (OD) was measured at $595 \mathrm{~nm}$ using a microplate reader (BioRad 680XR, Hertfordshire, UK) and again after incubation for $24 \mathrm{~h}$ at $37^{\circ} \mathrm{C}$. The MIC was determined as the lowest essential oil concentration. The OD at $24 \mathrm{~h}$ of the inoculum remained the same or reduced compared with that at the initial reading.

The MBC was measured by injecting $20 \mu \mathrm{L}$ of solution from 96-well microplate which was determined as the MIC value into MHA media in Petri dish, then was spread using drigalski spatula. On the basis of the MBC/MIC ratio the antibacterial impact was considered bactericidal or bacteriostatic. The MBC values were identified as the lowest sample concentration, resulting in the initial inoculum being killed by approximately $99.9 \%$.

\section{Scanning electron microscopy (SEM)}

SEM was conducted following the method by Ozogul et al. [20], aimed at examining the further effects of clove and cinnamon essential oils on morphological changes in bacterial cell walls. The essential oils of cloves and cinnamon were put into the broth culture at the MIC of each tested bacteria and incubated for $24 \mathrm{~h}$ at $37^{\circ} \mathrm{C}$. After incubation, each tube was centrifuged for $10 \mathrm{~min}$ at $4000 \times g$ at $4^{\circ} \mathrm{C}$. The samples were then washed twice with distilled water and resuspended in $1 \mathrm{~mL}$ water. After that, $10 \mu \mathrm{L}$ of the suspension was coated on the slide $(1 \times 1 \mathrm{~cm})$. This sample is then placed in a vertical laminar flow biological cabinet (Telstar Class II Cabinet, Terrassa, Spain) at $25^{\circ} \mathrm{C}$ to be dehydrated using $10 \%$ ethanol. The prepared sample was put into a desiccator until it was coated with gold in a sputter ion coating (Quorum Technologies Ltd., East Sussex, UK) for $10 \mathrm{~min}$ and then observed using SEM (Quanta 650 Field Emission SEM, FEI, Hillsboro, OR, USA).

\section{Results}

Antibacterial activity of clove and cinnamon essential oils

The antibacterial activity of clove and cinnamon essential oils was tested using two standard strains, and ESBL-producing E. coli isolate originating from chicken meat showed zones of inhibition around the disk, and the diameter of zones is presented in Table-3. It was found that clove essential oil (concentration of $40 \%, 20 \%$, and $10 \%$ ) was potentially active against $E$. coli ATCC 25922, K. pneumoniae ATCC 700603, and ESBL-producing E. coli from chicken meat with inhibition zones ranging from $15.0 \pm 1.00$ to $24.3 \pm 0.57 \mathrm{~mm}$. In addition, cinnamon essential oil (concentration of $40 \%, 20 \%$, and $10 \%$ ) was also potentially active against $E$. coli ATCC 25922, $K$. pneumoniae ATCC 700603, and ESBL-producing $E$. coli from chicken meat with zone size ranging from $15.6 \pm 2.08$ to $25.3 \pm 0.57 \mathrm{~mm}$ (Table-3).

\section{MIC and MBC of clove and cinnamon essential oils}

Determination of MIC was performed to determine the antibacterial activity of clove and cinnamonessential oils. Cinnamon essential oil showed a higher antibacterial effect on ESBL-producing E. coli from chicken meat (lowest MIC) than clove essential oil. The MIC value of clove essential oil was $0.078 \%$ against all strains tested. Meanwhile, the MIC value of cinnamon essential oil ranged from $0.039 \%$ to $0.156 \%$, as shown in Table- 4 .

In this study, clove essential oil exhibited antibacterial activity. The MIC for clove essential oil was

Table-3: Inhibition zone of clove and cinnamon essential oil against each tested bacteria.

\begin{tabular}{lccc}
\hline Treatment & \multicolumn{3}{c}{ Zone of inhibition (mm) } \\
\cline { 2 - 4 } & $\begin{array}{c}\text { Escherichia } \\
\text { coli ATCC } \\
\mathbf{2 5 9 2 2}\end{array}$ & $\begin{array}{c}\text { Klebsiella } \\
\text { pneumoniae } \\
\text { ATCC } \\
\text { 700603 }\end{array}$ & $\begin{array}{c}\text { Escherichia } \\
\text { coli ESBL } \\
\text { from } \\
\text { chicken } \\
\text { meat }\end{array}$ \\
\hline Clove 10\% & $17.0 \pm 1.73$ & $15.0 \pm 1.00$ & $15.3 \pm 2.30$ \\
Clove 20\% & $19.3 \pm 0.57$ & $17.3 \pm 0.57$ & $18.0 \pm 2.00$ \\
Clove 40\% & $24.3 \pm 0.57$ & $19.0 \pm 1.00$ & $22.6 \pm 2.08$ \\
Cinnamon 10\% & $15.6 \pm 2.08$ & $16.3 \pm 1.52$ & $17.3 \pm 1.15$ \\
Cinnamon 20\% & $18.6 \pm 1.15$ & $19.3 \pm 0.57$ & $20.6 \pm 1.15$ \\
Cinnamon 40\% & $21.3 \pm 2.30$ & $23.0 \pm 1.00$ & $25.3 \pm 0.57$ \\
Control (+)* & $34.6 \pm 1.15$ & $34.0 \pm 2.00$ & $34.0 \pm 2.00$ \\
Control (-)** & $6.0 \pm 0.00$ & $6.0 \pm 0.00$ & $6.0 \pm 0.00$ \\
\hline *=Positive control using Chloramphenicol, **=Negative \\
control using DMSO
\end{tabular}


at $0.078 \%(\mathrm{v} / \mathrm{v})$ for all strains tested. The MBC values of clove essential oil were at $0.078-0.156 \%$. The lowest MBC value was observed in E. coli ATCC 25922, and the highest $\mathrm{MBC}$ value was observed in $K$. pneumoniae ATCC 700603 and ESBL-producing E. coli from chicken meat.

Cinnamon essential oil hadMIC in the range of $0.039-0.156 \%$, whereas its $\mathrm{MBC}$ was at $0.078 \mathrm{v} 0.156 \%$. The highest MIC value was observed in E. coli ATCC 25922, whereas the lowest MIC value was shown in ESBL-producing E. coli from chicken meat. The lower $\mathrm{MBC}$ value found for cinnamon essential oil was shown in ESBL-producing E. coli from chicken meat, and a higher MBC value was shown in $E$. coli ATCC 25922 and K. pneumoniae ATCC 700603.

From the obtained MBC/MIC ratio (Table-4), it can be noticed that clove and cinnamon essential oils indicated a bactericidal effect against all strains of bacteria tested. MBCs were equal to or 2-fold greater than the MICs. The MBC/MIC ratios ranged from 1 to 4 , which were considered bactericidal [21].

\section{SEM}

Morphological changes in each tested bacterial cell were observed through SEM. The untreated tested bacteria showed normal cell shape, whereas each tested bacteria treated with clove and cinnamon essential oils showed shrinkage and cell lysis (Figure-1).

\section{Discussion}

The increasing incidence of ESBL-producing bacteria is widely spread from farms to slaughterhouses to animal-based food products. It is a health concern affecting animal and human health. The strategy for managing the spread of resistant bacteria has been extensively studied, including natural compounds being one of the alternative therapies for resistant bacteria.

Clove and cinnamon essential oils were active in inhibiting E. coli ATCC 25922, K. pneumoniae ATCC 700603, and ESBL-producing E. coli from chicken meat at $40 \%, 20 \%$, and $10 \%$ concentrations using the disk diffusion method. Essential oils with an inhibition zone diameter $>7 \mathrm{~mm}$ againstESBL-producing bacteriaare known to have effective antibacterial activity [22]. The antibacterial activity of cloves and cinnamon has been widely reported [6,23]; in this study, we tested the antibacterial activity of clove and cinnamon essential oils against ESBL-producing bacteria as a comparison to the previous studies $[8,9,23]$.
Clove and cinnamon essential oils have the same antibacterial effect on all bacteria tested. The MBC/ MIC ratios of clove and cinnamon essential oils ranged from 1 to 2. MBC that is close to MIC demonstrated good bactericidal activity against the tested strains. The MICs of clove and cinnamon essential oils in this study were similar to those in previously reported studies [24-26], with little differences, due to several reasons such as differences in the growing environments of clove and cinnamon, different extraction methods of essential oils and maybe the use of ESBLproducing bacteria as strains tested in this study.

The effect of clove and cinnamon essential oils on E. coli ATCC 25922, K. pneumoniae ATCC 700603, and ESBL-producing E. coli from chicken meat observed through SEM showed changes in bacterial cell structure (Figure-1). The untreated E. coli ESBL cells from chicken meat, E. coli ATCC 25922, and $K$. pneumoniae ATCC 700603 showed intact and smooth cell membrane surfaces, whereas $E$. coli ATCC 25922 and E. coli ESBL cells from chicken meat treated with clove and cinnamon essential oils showed rough and damaged cell membranes; some cells were lysed and split because of wrinkle formation. Meanwhile, K. pneumoniae ATCC 700603 cells treated with clove and cinnamon essential oils showed several cells that were elongated and lysed. Similar results were reported by several other researchers previously $[27,28]$.

As listed in Tables-1 and 2, clove buds and cinnamon bark harbor various essential oils that have different antibacterial activities. Clove bud contains $15-20 \%$ essential oil, dominated by eugenol (70$85 \%)$, eugenyl acetate $(15 \%)$, and $\beta$-caryophyllene $(5-12 \%)$ [7]. Eugenol is a bioactive compound with bactericidal damaging activities, such as holes in the envelope and bacterial cell deformities [29]. Cinnamon bark contains $0.5-1 \%$ essential oil consisting of cinnamaldehyde $(63.69 \%)$, cinnamyl acetate $(9.93 \%)$, and 1,8-cineole (8.75\%) [8]. Cinnamaldehyde also has a bactericidal activity that can affect the permeability and integrity of the membrane and morphology of bacterial cells [27].

On the basis of our findings, clove and cinnamon essential oils have antibacterial activity and are equally effective against K. pneumoniae ATCC 700603 and ESBL-producing $E$. coli from chicken meat that are resistant to $\beta$-lactam antibiotics and $E$. coli ATCC 25922 that is not resistant to $\beta$-lactam antibiotics.

Table-4: The MIC and MBC values of clove and cinnamon essential oils against each tested bacteria.

\begin{tabular}{lccccccc}
\hline \multirow{2}{*}{ Bacteria } & \multicolumn{3}{c}{ Clove } & & \multicolumn{3}{c}{ Cinnamon } \\
\cline { 2 - 3 } \cline { 6 - 8 } & MIC & MBC & MBC/MIC & MIC & MBC & MBC/MIC \\
\hline Escherichia coli ATCC 25922 & $0.078 \%$ & $0.078 \%$ & 1 & & $0.156 \%$ & $0.156 \%$ & 1 \\
Klebsiella pneumoniae ATCC 700603 & $0.078 \%$ & $0.156 \%$ & 2 & & $0.078 \%$ & $0.156 \%$ & 2 \\
Escherichia coli ESBL from chicken meat & $0.078 \%$ & $0.156 \%$ & 2 & & $0.039 \%$ & $0.078 \%$ & 2 \\
\hline
\end{tabular}




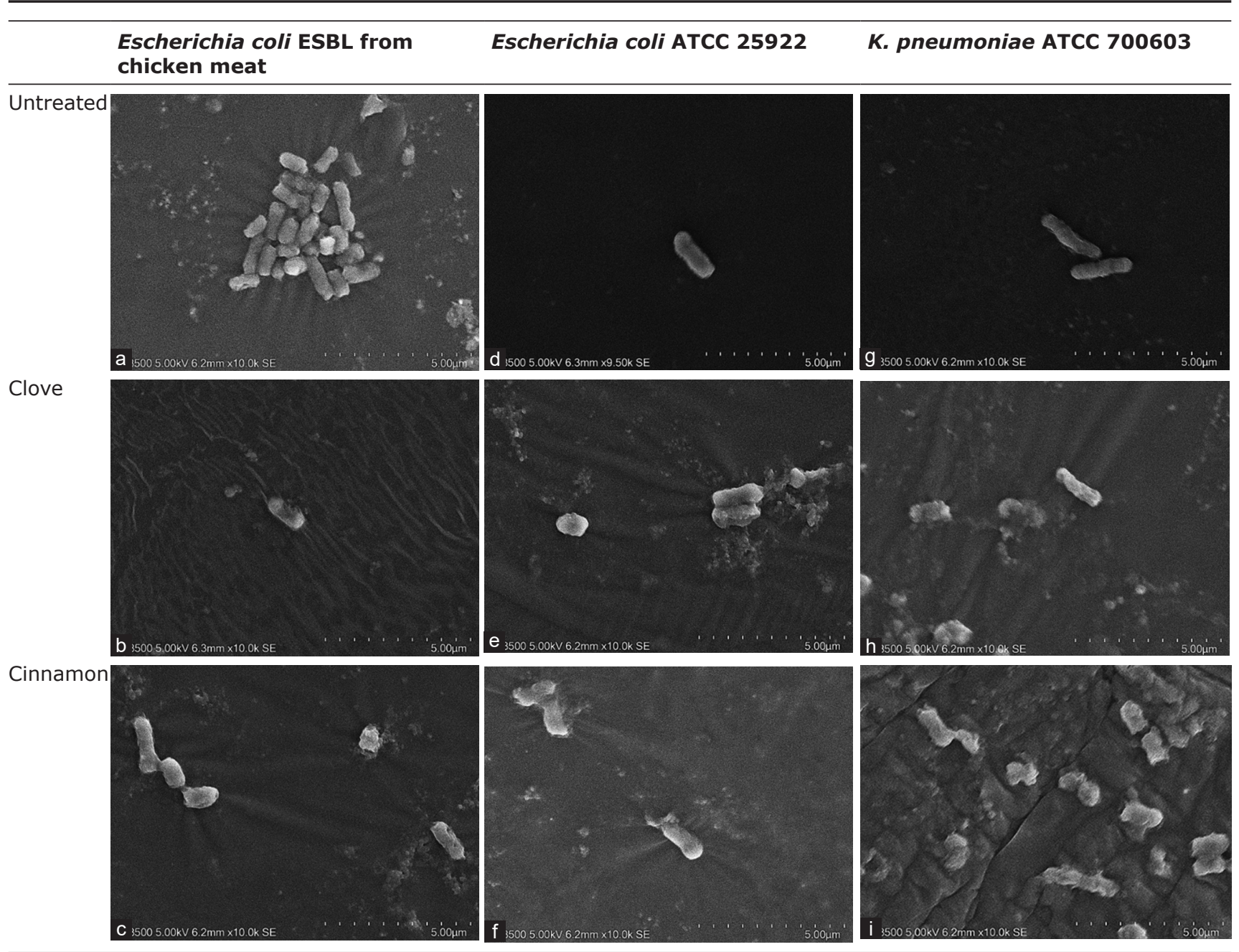

Figure-1: Morphological changes on each tested bacteria cells were observed by scanning electron microscopy (SEM). The untreated each tested bacteria showed normal cell shaped, while each tested bacteria treated with clove and cinnamon oil showed shrinkage and lysis cell. a: Escherichia coli ESBL from chicken meat untreated, b: E. coli ESBL from chicken meat treated with clove, c: E. coli ESBL from chicken meat treated with cinnamon, d: E. coli ATCC 25922 untreated, e: $E$. coli ATCC 25922 treated with clove, f: E. coli ATCC 25922 treated with cinnamon, g: Klebsiella pneumoniae ATCC 700603 untreated, h: K. pneumoniae ATCC 700603 treated with clove, i: K. pneumoniae ATCC 700603 treated with cinnamon.

\section{Conclusion}

This study reveals that clove and cinnamon essential oils have emerged as effective agents by showing high antibacterial activity against each bacteria tested, indicated by the inhibition zone diameter and MIC value. On the basis of the data, clove and cinnamon essential oils can be recommended as bioactive compounds to control the spread of ESBL-producing E. coli and K. pneumoniae isolates.

\section{Authors' Contributions}

EVG: Collected samples, conducted research in the laboratory, analyzed the data, and wrote the manuscript. DAW and ER: Delivered reagents and materials, analysis of the results, examined the data, and wrote and critically revised the manuscript. All authors read and approved the final manuscript.

\section{Acknowledgments}

The authors would like to thank Universitas Gadjah Mada, Indonesia, for funding this research through the Grant of Final Assignment Recognition Program 2020 (Grant no.: 2607/UN1/DITLIT/DIT-LIT/PT/2020). The authors are also thankful to Laboratory staff from Faculty of Veterinary Medicine and Faculty of Biology Universitas Gadjah Mada, Yogyakarta, Indonesia as well as staff of the Integrated Research Testing and Laboratory, Universitas Gadjah Mada, Yogyakarta, Indonesia, who supported this research.

\section{Competing Interests}

The authors declare that they have no competing interests.

\section{Publisher's Note}

Veterinary World remains neutral with regard to jurisdictional claims in published institutional affiliation. 


\section{References}

1. Friedman, M. (2015) Antibiotic-resistant Bacteria: Prevalence in food and inactivation by food-compatible compounds and plant extracts. J. Agric. Food Chem., 63(15): 3805-3822.

2. Faujdar, S.S., Bisht, D. and Sharma, A. (2020) Antibacterial activity of Syzygium aromaticum (clove) against uropathogens producing ESBL, MBL, and AmpC beta-lactamase: Are we close to getting a new antibacterial agent. J. Family Med. Prim. Care., 9(1): 180-186.

3. Retnaningrum, E., Yossi, T., Nur'azizah, R., Sapalina, F. and Kulla, P.D.K. (2020) Characterization of a bacteriocin as bio preservative synthesized by indigenous lactic acid bacteria from dadih soya traditional product used in West Sumatra, Indonesia. Biodiversitas, 21(9): 4192-4198.

4. Faujdar, S.S., Bisht, D. and Sharma, A. (2020) Antibacterial potential of neem (Azadirachta indica) against uropathogens producing beta-lactamase enzymes: A clue to future antibacterial agent. Biomed. Biotechnol. Res. J., 4(3): 232-238.

5. Anzlovar, S., Baricevic, D., Avgustin, J.A. and Koce, J.D. (2014) Thyme essential oil as an antibacterial additive. Food Technol. Biotechnol., 52(2): 263-268.

6. Hoque, M.M., Bari, M.L., Juneja, V.K. and Kawamoto, S. (2008) Antibacterial activity of cloves and cinnamon extracts against foodborne pathogens and spoilage bacteria, and inactivation of listeria monocytogenes in ground chicken meat with their essential oils. Rep. Natl. Food Res. Inst., 72: 9-21.

7. Mittal, M., Gupta, N., Parashar, P., Mehra, V. and Khatri, M. (2014) Phytochemical evaluation and pharmacological activity of Syzygium aromaticum. Int. J. Pharm. Sci., 6(8): 67-72.

8. Abdel-Moaty, M.M., El-Hendawy, H.H., Mohamed, W.S. and Abdel-All, S.M. (2016) A potential role of cinnamon bark essential oil and its major component in enhancing antibiotics effect against clinical isolates of extended-spectrum beta-lactamase producing Escherichia coli. Der Pharm. Lett., 8(7): 138-147.

9. Qian, W., Sun, Z., Wang, T., Yang, M., Liu, M., Zhang, J. and Li, Y. (2019) Antibacterial activity of eugenol against carbapenem-resistant Klebsiella pneumoniae and its effect on biofilms. Microb. Pathogen., 139: 103924.

10. He, T.F., Wang, L.H., Niu, D., Wen, Q. and Zeng, X.A. (2018) Cinnamaldehyde inhibit Escherichia coli associated with membrane disruption and oxidative damage. Arch. Microbiol., 201(4): 451-458.

11. Rehab, M.A.E. and Zeinab, S.H. (2016) Eugenol and linalool: Comparison of their antibacterial and antifungal activities. Afr. J. Microbiol. Res., 10(44): 1860-1872.

12. Hosseini, M., Jamshidi, A., Raeisi, M. and Azizzadeh, M. (2020) Effect of sodium alginate coating containing clove (Syzgium Aromaticum) and lemon verbena (Aloysia Citriodora) essential oils and different packaging treatments on shelf life extension of refrigerated chicken breast. J. Food Proc. Preserv., 45(3): e14946.

13. Khare, A.K., Abraham, R.J.J., Rao, V.A. and Babu, R.N. (2016) Utilization of carrageenan, citric acid and cinnamon oil as an edible coating of chicken fillets to prolong its shelf life under refrigeration conditions. Vet. World, 9(2): 166-175.

14. Masango, P. (2005) Cleaner production of essential oils by steam distillation. J. Cleaner Prod., 13(8): 833-839.
15. Gaylor, R., Michel, J., Thierry, D., Panja, R., Fanja, F. and Pascal, D. (2014) Bud, leaf and stem essential oil composition of Syzygium aromaticum from Madagascar, Indonesia and Zanzibar. Int. J. Basic Appl. Sci., 3(3): 2473.

16. Plumeriastuti, H., Budiastuti, B., Effendi, M.H. and Budiarto, B. (2019) Identification of bioactive compound of the essential oils of Cinnamomum burmannii from several areas in Indonesia by gas chromatography-mass spectrometry method for antidiabetic potential. Natl. J. Physiol. Pharm. Pharmacol., 9(4): 279-283.

17. Balouiri, M., Sadiki, M. and Ibnsouda, S.K. (2016) Methods for in vitro evaluating antimicrobial activity: A review. $J$. Pharm. Anal., 6(2): 71-79.

18. Gulfraz, M., Mehmood, S., Minhas, N., Jabeen, N., Kausar, R., Jabeen, K. and Arshad, G. (2008) Composition and antibacterial properties of essential oil of Foeniculum vulgare. Afr. J. Biotechnol., 7(24): 4364-4368.

19. Adukwu, E.C., Allen, S.C.H. and Phillips, C.A. (2012) The anti-biofilm activity of lemongrass (Cymbopogon flexuosus) and grapefruit (Citrus paradisi) essential oils against five strains of Staphylococcus aureus. J. Appl. Microbiol., 113(5): 1217-1227.

20. Ozogul, Y., Kuley Boğa, E., Akyol, I., Durmus, M., Ucar, Y., Regenstein, J.M. and Köşker, A.R. (2020) Antibacterial activity of thyme essential oil nanoemulsions on spoilage bacteria of fish and foodborne pathogens. Food Biosci., 36: 100635 .

21. Levison, M.E. (2004) Pharmacodynamics of antibacterial drugs. Infect. Dis. Clin. North Am., 18(3): 451-465.

22. Prabuseenivasan, S., Jayakumar, M. and Ignacimuthu, S. (2006) In vitro antibacterial activity of some plant essential oils. BMC Complement Altern. Med., 6(39): 1-8.

23. Dhara, L. and Tripathi, A. (2013) Antibacterial activity of eugenol and cinnamaldehyde against extended-spectrum beta-lactamase producing Enterobacteriaceae by in vitro and molecular docking analysis. Eur. J. Integrat. Med., 5(6): 527-536.

24. Zhang, Y., Liu, X., Wang, Y., Jiang, P. and Quek, S. (2015) Antibacterial activity and mechanism of cinnamon essential oil against Escherichia coli and Staphylococcus aureus. Food Control, 59: 282-289.

25. Siddiqua, S., Anusha, B.A., Ashwini, L.S. and Negi, P.S. (2014) Antibacterial activity of cinnamaldehyde and clove oil: Effect on selected foodborne pathogens in model food systems and watermelon juice. J. Food Sci. Technol., 52(9): 5834-5841.

26. Ebani, V., Najar, B., Bertelloni, F., Pistelli, L., Mancianti, F. and Nardoni, S. (2018) Chemical composition and in vitro antibacterial efficacy of sixteen essential oils against Escherichia coli and Aspergillus fumigatus isolated from Poultry. Vet. Sci., 5(3): 62.

27. Shen, S., Zhang, T., Yuan, Y., Lin, S., Xu, J. and Ye, H. (2014) Effects of cinnamaldehyde on Escherichia coli and Staphylococcus aureus membrane. Food Control. 47: 196-202.

28. El-Baky, R.M.A. and Hasem, Z.S. (2016) Eugenol and linalool: Comparison of their antibacterial and antifungal activities. Afr. J. Microbiol. Res., 10(44): 1860-1872.

29. Walsh, S.E., Maillard, J.Y., Russell, A.D., Catrenich, C.E., Charbonneau, D.L. and Bartolo, R.G. (2003) Activity and mechanisms of action of selected biocidal agents on Grampositive and-negative Bacteria. J. Appl. Microbiol., 94(2): 240-247. 